《Reseach Note》

\title{
Effect of Cyclic Environmental Temperatures upon Oviposition Patterns in Domestic Fowl
}

\author{
Takashi UENo \\ National Institute of Animal Industry, Tsukuba Norindanchi P. O. Box 5, Ibaraki 305, Japan
}

\section{Introduction}

Several workers reported that the time of oviposition can be altered by manipulating light and darkness and that under constant illumination oviposition are distributed throughout 24 hours $^{1 \sim 3)}$. PAYNe et al. ${ }^{4)}$ and Bhatti and Morris ${ }^{5)}$ found a similar effect due to variation in environmental temperature. BHATTI and MORRIS ${ }^{5)}$ concluded that thermoperiods can have subsidiary effect even in the presence of a clear light-dark cycle and if the light to dark ratio is altered substantially there comes a point at which the influence of cyclic temperature becomes dominant. Because little is known about the effect of thermoperiod on egg laying pattern, this study was undertaken to obtain further information.

\section{Materials and Methods}

One hundred and twenty White Leghorn hens (8-month-old) were used in this study. The birds were placed in individual cages in temperature controlled room in Zootron facilities of National Institute of Animal Industry. Feed (CP: 15.5\%, ME: $2.48 \mathrm{kcal} / \mathrm{g}$ ) and water were provided ad libitum, and no regular feeding time adopted. The hens were kept on a continuous illumination. Light intensity was 500 lux at the level of the cage floor. The hens were subjected to the following temperature schemes: 1) $33^{\circ} \mathrm{C}$ constant, 2) $27-33^{\circ} \mathrm{C}$ cyclic, 3) $21-33^{\circ} \mathrm{C}$ cyclic, 4) $15-33^{\circ} \mathrm{C}$ cyclic. A period of 2 weeks was allowed for adaptation before treatment response was studied. On cyclic temperature treatments, the maximum temperature was attained at $12: 00$ and then immediately began to decline to the minimum temperature at $24: 00$ (Fig. 1). Relative humidity was held constant at $60 \pm$ $5 \%$. The floor of the cage was sloped to allow an egg to roll toward the front of the cage and strike a trip-bar attached to a microswitch to record oviposition time. The signals from the microswitches were directed to the mini-computer system (OKITAC 40/50, Oki Electric Co., LTD.), and the time of oviposition were recorded on a magnetic disk.

\section{Results and Discussion}

The results of this study are illustrated in Fig. 1. The distributions of oviposition times under cyclic temperature regimens may almost correspond to the pattern of temperature change, while the oviposition times were equally distributed throughout $24 \mathrm{hr}$. under con- 


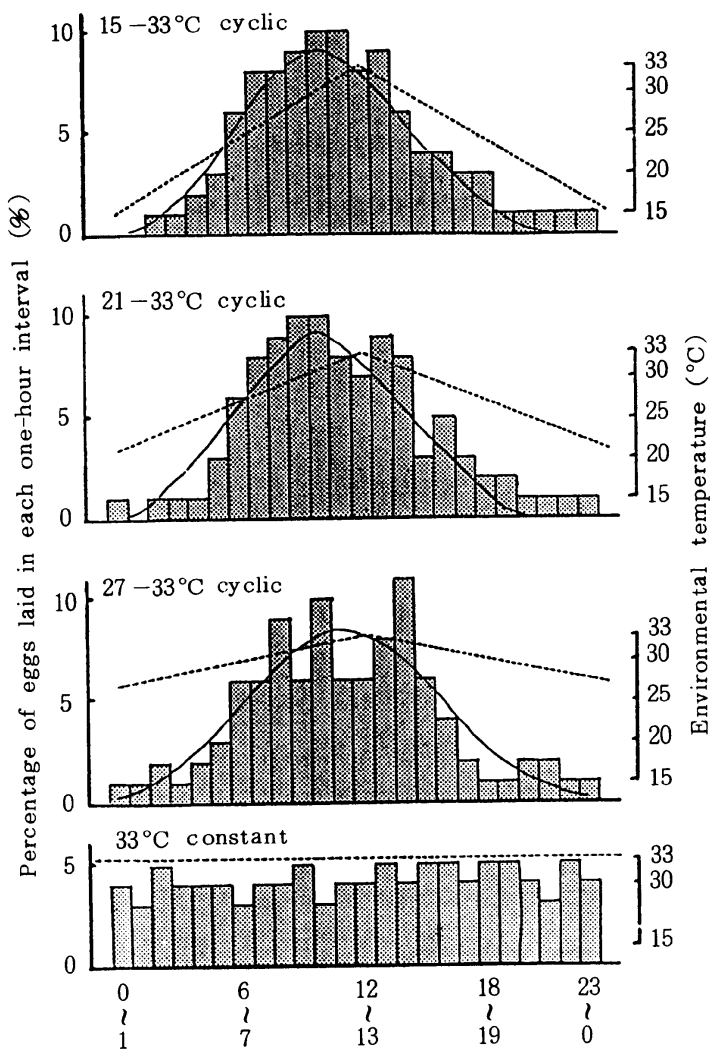

Fig. 1 Distribution of oviposition time under constant and cyclic temperature regimens.

Estimated normal distribution curve $(-)$ and temperature cycle $(\cdots)$ were superimposed.

stant temperature regimen. When temperature were cycled diurnally, the frequency distribution was increased by increasing temperature and decreased by decreasing temperature. These results were equivalent to the findings of Payne et al. ${ }^{4)}$, CAIN and WILson ${ }^{6)}$ and BHATTI and MORRIS ${ }^{5)}$ who showed that the eggs were laid in the hot phase with a temperature cycles and continuous illumination. It appears from these results that the thermoperiodic signal, like photoperiodic signal, is effective as a Zeitgeber (time giver) for entraining oviposition rhythms.

While previous reports ${ }^{4,5}$ ) suggest that the temperature cycles with large difference, more than $10^{\circ} \mathrm{C}$, in hot and cool phase are effective in synchronizing the oviposition time, the results in present experiment indicate that the diurnal temperature cycles with small differences $\left(6^{\circ} \mathrm{C}\right)$ in the two phases are effective in altering the oviposition pattern. Thus, the distribution pattern of oviposition time may have been influenced by the temperature range. Namely, as the temperature range become narrower, the distribution curve have a tendency to become gentler. However, no differences in oviposition pattern were observed between two treatments $\left(21-33^{\circ} \mathrm{C}, 15-33^{\circ} \mathrm{C}\right)$. These similarity presented here may suggested that the thermal effects of diurnal temperature fluctuation on oviposition are almost equivalent, be- 
cause minimum temperatures $\left(15,21^{\circ} \mathrm{C}\right)$ at both cycled temperatures are within the range of the zone of thermoneutrality ${ }^{7}$. Interestingly, regardless of the temperature cycles, oviposition peak occured 2-3 hours prior to temperature peak.

\section{Summary}

To study the effect of cyclic environmental temperature on oviposition pattern, one hundred and twenty White Leghorn hens were maintained at temperatures of 33, 27-33, 21$33,15-33^{\circ} \mathrm{C}$ with continuous light. When the temperatures were cycled diurnally, the frequency distribution of oviposition time was increased by increasing temperature and decreased by decreasing temperature. The distribution pattern of oviposition time may have been influenced by the temperature range. However, no differences in oviposition pattern were observed between two treatments $\left(21-33^{\circ} \mathrm{C}, 15-33^{\circ} \mathrm{C}\right)$. Also, present results indicate that regardless of the temperature cycles, oviposition peak occured 2-3 hours prior to temperature peak.

\section{Literatures}

1) Morris, J. A. (1961) The effect of continuous light and continuous noise on pullets held in a sealed chamber. Poult. Sci., 40: 995-1000.

2) Fraps, R. M. (1968) Timing of oviposition in White Leghorn hens under continuous uniform light. Archs. Anat. Histol. Embryol., 50: 225-230.

3) Naito, M., T. Ueno, T. Komiyama and Y. Miyazono (1980) Oviposition times under various light-dark cycles in domestic fowl. Japan. Poult. Sci., 17: 146-150.

4) Payne, C. G., D. W. Lincoln and D. R. Charles (1965) The influence of constant and fluctuating environmental temperatures on time of oviposition under continuous lighting. Br. Poult. Sci., 6: 93-95.

5) Bhatti, B. M. and T. R. Morris (1977) The relative importance of light and temperature as phase setting signals for oviposition in the fowl. Br. Poult. Sci., 18: 391-395.

6) CAIn, J. R. and W. O. Wilson (1973) The influence of specific environmental parameters on the circadian rhythms of chickens. Poult. Sci., 53: 1438-1447.

7) van Es, A. J. H., D. van Aggelen, H. J. Nijkamp, J. E. Vogt and C. W. Scheele (1973) Thermoneutral zone of laying hens kept in batteries. Z. Tierphysiol., Tierernährg. U. Futtermittelkde., 32: 121-129. 


\section{環境温度の周期的変化がニワトリの放卵}

$$
\text { パターンにおよぼす影響 }
$$

上 野 孝 志

農林水産省畜産試験場, 筑波農林研究団地内局 - 私書箱 5 号, 茨城 305

8 ケ月龄の白色レグホーン産卵鶏を用い, 周期的変温 環境が、ニワトリの放卵時刻におよぼす影響について検 討した。ニワトリは 24 時間連続照明下で, $33^{\circ} \mathrm{C}$ の一定な らびに $27 \sim 33^{\circ} \mathrm{C}, 21 \sim 33^{\circ} \mathrm{C}$ および $15 \sim 33^{\circ} \mathrm{C}$ の变温条件 に感作した。定温条件下では, 放卵時刻は 24 時間に亘 ってほぼ均一に分布したが，変温条件下では，いずれも 環境温度の上昇とともに放卵頻度が高まり，また下降と ともに放卵頻度も低下寸るという, 環境温度の上昇下降 にほぼ一致した分布を示した。また，温度較差が放卵分 布にも影響し, 温度較差の払がりにつれて分布の「尖度」
が大きくなる傾向がみられた。しかし，21〜33 ${ }^{\circ} \mathrm{C}$ 15〜 $33^{\circ} \mathrm{C}$ では，それぞれ $12^{\circ} \mathrm{C}$ と $18^{\circ} \mathrm{C}$ の温度 較差があるにも かかわらず, 放卵分布のパターンには殆んど差は認めら れなかった。この原因として, 両温度条件の下限温度 $\left(21^{\circ} \mathrm{C}, 15^{\circ} \mathrm{C}\right)$ が，ともに熱的中性圏にあることが考えら れた。放卵分布のピークは, いずれの変温条件下におい ても温度周期のピーク時刻 (12:00)より $2 \sim 3$ 時間前 に現われた。

（家禽会誌，22，327～330，1985） 